\title{
Dynamic Behavior of PET FRP and Its Preliminary Application in Impact Strengthening of Concrete Columns
}

\author{
Yu-Lei Bai ${ }^{1}$, Zhi-Wei Yan ${ }^{1}$, Togay Ozbakkaloglu ${ }^{2}$, Jian-Guo Dai ${ }^{3} \oplus$, Jun-Feng Jia ${ }^{1, *(1)}$ and \\ Jun-Bo Jia ${ }^{1}$ \\ 1 Key Laboratory of Urban Security and Disaster Engineering of Ministry of Education, Beijing University \\ of Technology, Beijing 100124, China; baiyulei@bjut.edu.cn (Y.-L.B.); yanzhw@126.com (Z.-W.Y.); \\ junbojia2001@yahoo.com (J.-B.J.) \\ 2 Ingram School of Engineering, Texas State University, San Marcos, TX 78667, USA; togay.oz@txstate.edu \\ 3 Department of Civil and Environmental Engineering, The Hong Kong Polytechnic University, \\ Hong Kong 999077, China; cejgdai@polyu.edu.hk \\ * Correspondence: jiajunfeng@bjut.edu.cn
}

Received: 15 October 2019; Accepted: 15 November 2019; Published: 20 November 2019

\begin{abstract}
Polyethylene terephthalate (PET) fiber has attracted significant attention for reinforced concrete (RC) structure rehabilitation due to its large rupture strain (LRS; more than 7\%) characteristic and recyclability from waste plastic bottles. This study presents a dynamic tensile test of PET fiber bundles performed using a drop-weight impact system. Results showed that the tensile strength and the elastic modulus of the PET fiber bundles increased, whereas the failure strain and the toughness decreased with the increasing strain rate from 1/600 to $160 \mathrm{~s}^{-1}$. In addition, the performance of concrete confined with the PET fiber-reinforced polymer (FRP) under impact loading was investigated based on a $75 \mathrm{~mm}$-diameter split Hopkinson pressure bar (SHPB) device and a drop-weight apparatus. For the SHPB test, owing to the large rupture strain property of PET FRP, the PET FRP-confined concrete exhibited significantly better performance under impact loading compared to its counterpart confined with carbon FRPs (CFRPs). During the drop-weight test, the confinement of the PET FRP composites to the concrete columns as external jackets not only improved the peak impact force, but also prolonged the impact process.
\end{abstract}

Keywords: composite materials; polymeric composites; PET FRP; dynamic behavior

\section{Introduction}

Fiber-reinforced polymers (FRPs) have been widely used for seismic strengthening of existing reinforced concrete (RC) structures, owing to their advantages of high strength-to-weight ratios, corrosion resistance, and superior durability [1-14]. Considering the fact that the existing RC columns may be subjected to not only seismic loading but also dynamic loading such as vehicle/boat impact during their service life [15], the investigations of impact behaviors of RC structures strengthened with FRP composites are of vital importance for the application of FRPs in the impact-resistant design of RC structures. Although extensive studies of impact-resistant behaviors of conventional concrete and RC structures have been conducted [16-21], only a few studies of impact-resistant behaviors of FRP-confined concrete were conducted [22-27].

Xiao and Shen [23] conducted the drop-weight test to investigate the impact-resistant behaviors of the concrete-filled steel tube column confined with carbon FRPs (CFRPs) and found that the damage of the specimen could be reduced with the application of CFRPs as external jackets. Huang et al. [26] investigated the impact-resistant behaviors of the glass FRP (GFRP)-SR (spiral reinforcement)-confined 
concrete columns and found that an increase in the thickness of the GFRP tube led to an increase in the impact-resistant behaviors of the specimen. Yang et al. [27] used a $100 \mathrm{~mm}$-diameter split Hopkinson pressure bar (SHPB) apparatus to investigate the dynamic mechanical behaviors of the concrete confined with aramid FRPs (AFRPs). The experimental results showed that the dynamic compressive strength, ultimate strain, and toughness of the concrete were remarkably increased with the application of the external AFRP jacket to confine the core concrete.

Considering the fact that the FRP mainly bears tensile force in the strengthening of the structures and the fiber bundles are the main load-bearing element in FRP composites, the dynamic tensile mechanical properties of fiber bundles are necessary for studying the failure mechanism between the FRP and the concrete under impact loading. To address this issue, some studies have been reported to date. Ou et al. [28] investigated the strain rate effect on the dynamic tensile mechanical properties of the glass-fiber bundle specimen and found that the tensile strength increased with the increasing strain rate from $1 / 600$ to $160 \mathrm{~s}^{-1}$. Zhu et al. [29] investigated the effect of the strain rate (20 to $100 \mathrm{~s}^{-1}$ ) on the dynamic tensile mechanical properties of the Kevlar 49 fiber bundle specimen. The experimental results showed that the tensile strength, the elastic modulus, and the toughness increased with the increasing strain rate.

The past decade has witnessed the emergence of a new type of FRP composite, polyethylene terephthalate (PET) [30-42]. Research has shown that its very large rupture strain (i.e., more than $7 \%$ ) may lead to enhanced structural ductility and impact energy dissipation in the impact-resistant retrofitting/strengthening of RC structures [43]. This paper briefly presents the authors' recent studies on the dynamic tensile mechanical properties of PET fiber bundles and the dynamic compressive behavior of concrete confined by the PET FRP. The preliminary results illustrated the great potential of the use of PET FRP in impact strengthening applications of RC structures at the material (i.e., PET fiber bundle and PET FRP-confined concrete) and component (i.e., PET FRP-confined concrete column) levels. It is expected that the results presented here will facilitate further investigation of the impact-resistant behavior of PET FRP-strengthened RC structures.

\section{Materials and Methods}

\subsection{Dynamic Tensile Test of PET Fiber Bundles}

A typical specimen was fabricated with a gauge length of $25 \mathrm{~mm}$ (Figure 1) according to $\mathrm{Ou}$ et al. [28]. A long fiber bundle with a $1800 \mathrm{~mm}$ length was extracted from the unidirectional PET fiber fabric and weighed by an electronic balance to obtain a mass of $0.307 \mathrm{~g}$. The linear density $\left(1.7 \times 10^{-3} \mathrm{~g} / \mathrm{cm}\right)$ could be calculated by dividing the mass by the length, and the area of the transverse section of the bundle $\left(1.23 \times 10^{-3} \mathrm{~cm}^{2}\right)$ could be obtained by dividing the linear density by the bulk density $\left(1.38 \mathrm{~g} / \mathrm{cm}^{3}\right)$ that was provided by the manufacturer (Maeda Kosen Co., Sakai-shi, Japan). A fiber bundle with a length of $60 \mathrm{~mm}$ was cut from the extracted long fiber bundle. Two aluminum sheets with a length of $20 \mathrm{~mm}$, a width of $15 \mathrm{~mm}$, and a thickness of $0.2 \mathrm{~mm}$ were roughhewed by a serrated steel plate and folded along the long side to catch the fiber bundle using the epoxy resin. After the resin was fully cured and the redundant fiber bundle at both sides was cut off, a fiber bundle specimen with a gauge length of $25 \mathrm{~mm}$ was completed.

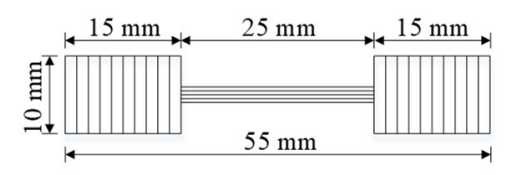

Figure 1. Schematic diagram of a fiber bundle specimen.

Five PET fiber bundle specimens were tested for each displacement rate of 1, 2, 3, and $4 \mathrm{~m} / \mathrm{s}$ with the respective strain rates of $40,80,120$, and $160 \mathrm{~s}^{-1}$, which is the ratio of the displacement rate to the corresponding gauge length of the specimen, using an Instron drop-weight impact system (Figure 2). 
The impact height of the system ranged from 0.03 to $1.10 \mathrm{~m}$, and the maximum mass of a drop hammer was $37.5 \mathrm{~kg}$. The drop hammer dropped freely along the guide rail and impacted the specimen after the release of the drop hammer.

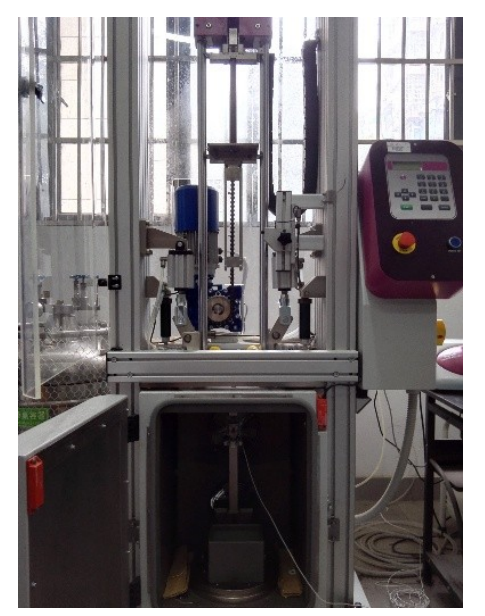

Figure 2. Instron drop-weight impact system.

For comparison, five PET fiber bundle specimens were also tested under quasi-static conditions at a crosshead speed of $2.5 \mathrm{~mm} / \mathrm{min}$ (strain rate of $1 / 600 \mathrm{~s}^{-1}$ ) using an MTS universal testing machine. The loading capacity of the MTS system ranges from 0.1 to $30 \mathrm{kN}$ with a data sampling rate of $1 \mathrm{kHz}$. The tension of the PET fiber bundle specimen was measured with a force sensor, of which the maximum range and the data acquisition rate are $1 \mathrm{kN}$ and $20 \mathrm{~Hz}$, respectively. The deformation of the PET fiber bundle specimen was considered as the displacement of the upper beam of the system, due to the fact that the stiffness of the specimen was far lower than that of the loading system [44].

\subsection{Split Hopkinson Pressure Bar Test}

Concrete cylinders with a diameter of $150 \mathrm{~mm}$ and a height of $305 \mathrm{~mm}$ were cast with ordinary Portland cement, river sand, and crushed granitic rocks with a particle size ranging from 5 to $10 \mathrm{~mm}$. The average 28-day compressive strength of the concrete was $18.5 \mathrm{MPa}$.

A total of 9 concrete columns with a $70 \mathrm{~mm}$ diameter and a $38 \mathrm{~mm}$ height were prepared. Among them, 3 concrete cylinders were wrapped with one layer of the PET FRP, of which the nominal thickness, the tensile strength, and the elastic modulus were $0.841 \mathrm{~mm}, 751 \mathrm{MPa}$, and $17.9 \mathrm{GPa}$, respectively, 3 concrete cylinders were wrapped with two layers of the PET FRP, and 3 specimens were wrapped with one layer of the CFRP, of which the nominal thickness, the tensile strength, and the elastic modulus were $0.165 \mathrm{~mm}, 4423 \mathrm{MPa}$, and $240 \mathrm{GPa}$, respectively, for the purpose of the comparison (Table 1), according to the manual wet layup way [30]. A continuous fiber sheet saturated with the epoxy resin, mixed at a ratio of the main resin component L-500AS to the hardener L-500BS of 2:1 (provided by SANYU Shanghai Company), was wrapped around the concrete cylinder with the fibers orientated in the hoop direction of the cylinder. To prevent the debonding failure, a fiber sheet with a length of $350 \mathrm{~mm}$ (i.e., one circumference + half circumference of the overlapping zone) was used for the fabrication of one-layer FRP-confined concrete specimens. To reduce the test scatter, three identical specimens were tested at each impact velocity using a $75 \mathrm{~mm}$-diameter SHPB device to investigate the dynamic compressive behavior of the FRP-confined concrete (Figure 3). The apparatus comprised an energy source, a $600 \mathrm{~mm}$-long projectile, a $5000 \mathrm{~mm}$-long incident bar, a $3000 \mathrm{~mm}$-long transmission bar, a digital oscilloscope, and a velocity testing system that was used to record the initial velocity of the projectile. 
Table 1. Summary of specimens for the SHPB test.

\begin{tabular}{cccccccccc}
\hline $\begin{array}{c}\text { Type of } \\
\text { Test }\end{array}$ & $\begin{array}{c}\mathbf{D} \times \mathbf{H} \\
\mathbf{( m m )}\end{array}$ & Type of FRP & $\begin{array}{c}\text { Nominal } \\
\text { Thickness } \\
\text { of FRP } \\
\mathbf{( m m )}\end{array}$ & $\begin{array}{c}\text { Volume } \\
\text { Fraction } \\
\text { of Fiber }\end{array}$ & $\begin{array}{c}\text { Tensile } \\
\text { Strength } \\
\text { of FRP } \\
\mathbf{( M P a})\end{array}$ & $\begin{array}{c}\text { Number } \\
\text { of } \\
\text { Layers }\end{array}$ & $\begin{array}{c}\text { Initial } \\
\text { Velocity } \\
\mathbf{( m / s}\end{array}$ & $\begin{array}{c}\text { Unconfined } \\
\text { Concrete } \\
\text { Strength } \\
\text { (MPa) }\end{array}$ & $\begin{array}{c}\text { Number of } \\
\text { Identical } \\
\text { Specimen }\end{array}$ \\
\hline $\begin{array}{c}\text { SHPB } \\
\text { test }\end{array}$ & $70 \times 38$ & $\begin{array}{c}\text { Carbon FRP } \\
\text { (CFRP) }\end{array}$ & 0.165 & $15 \%$ & 4423 & 1 & 10.9 & 18.5 & 3 \\
& $70 \times 38$ & $\begin{array}{c}\text { Polyethylene } \\
\text { terephthalate } \\
\text { (PET) FRP }\end{array}$ & 0.841 & $31 \%$ & 751 & 1 & 11.4 & 18.5 & 3 \\
\hline
\end{tabular}

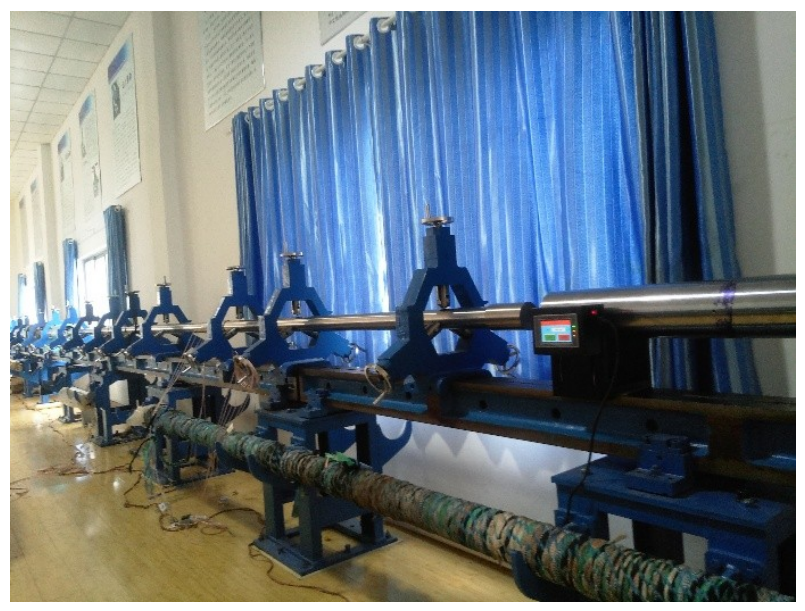

Figure 3. Split Hopkinson pressure bar (SHPB) apparatus.

The specimen was sandwiched between the incident and transmission bars. The stress wave was reshaped with a rubber shaper (1 $\mathrm{mm}$ in thickness and $20 \mathrm{~mm}$ in diameter) installed on the impact end of the incident bar. The time histories of the strain $\varepsilon(t)$, stress $\sigma(t)$, and strain rate $\dot{\varepsilon}(t)$ of the specimen can be obtained by Equations (1)-(3), according to the two-wave theory [27]:

$$
\begin{gathered}
\varepsilon(t)=\frac{2 C}{L_{s}} \int_{0}^{t}\left[\varepsilon_{i}(t)-\varepsilon_{t}(t)\right] \mathrm{d} t, \\
\sigma(t)=E \frac{A}{A_{s}} \varepsilon_{t}(t), \\
\dot{\varepsilon}(t)=\frac{2 C}{L_{s}}\left[\varepsilon_{i}(t)-\varepsilon_{t}(t)\right],
\end{gathered}
$$

where $\varepsilon_{i}(t)$ and $\varepsilon_{t}(t)$ are the strain of the incident and transmission bars, respectively; $A$ is the cross-sectional area of bars; $A_{\mathrm{s}}$ and $L_{\mathrm{s}}$ are the initial cross-sectional area and the height of the specimen, respectively.

\subsection{Drop-Weight Test}

Twelve concrete cylinders with a diameter of $95 \mathrm{~mm}$, a height of $285 \mathrm{~mm}$, and an average 28-day compressive strength of $58.5 \mathrm{MPa}$ were prepared. The preparation of the concrete column and the fabrication of the FRP-confined concrete column were the same as those presented in Section 2.2. Among them, 8 cylinders were wrapped with one layer of the PET FRP, 2 cylinders were confined with one layer of the AFRP, of which the nominal thickness, the tensile strength, and the elastic modulus are $0.169 \mathrm{~mm}, 3732 \mathrm{MPa}$, and $115 \mathrm{GPa}$, respectively, and 2 remaining unconfined concrete cylinders were tested as control specimens (Table 2). All specimens were denoted as "A-B-C", where A, B, and C stand for the type of FRP, the number of FRP layers, and the drop height, respectively. Two nominally identical specimens were tested at each drop height to reduce the data scatter. 
Table 2. Summary of specimens for the drop-weight impact test.

\begin{tabular}{|c|c|c|c|c|c|c|c|c|c|}
\hline $\begin{array}{c}\text { Type of } \\
\text { Test }\end{array}$ & $\begin{array}{l}D \times H \\
(\mathrm{~mm})\end{array}$ & Type of FRP & $\begin{array}{c}\text { Nominal } \\
\text { Thickness } \\
\text { of FRP } \\
(\mathbf{m m})\end{array}$ & $\begin{array}{l}\text { Volume } \\
\text { Fraction } \\
\text { of Fiber }\end{array}$ & $\begin{array}{c}\text { Tensile } \\
\text { Strength } \\
\text { of FRP } \\
\text { (MPa) }\end{array}$ & $\begin{array}{c}\text { Number } \\
\text { of } \\
\text { Layers }\end{array}$ & $\begin{array}{l}\text { Impact } \\
\text { Height } \\
\text { (m) }\end{array}$ & $\begin{array}{l}\text { Unconfined } \\
\text { Concrete } \\
\text { Strength } \\
\text { (MPa) }\end{array}$ & $\begin{array}{c}\text { Number of } \\
\text { Identical } \\
\text { Specimen }\end{array}$ \\
\hline \multirow{6}{*}{$\begin{array}{l}\text { Drop-weight } \\
\text { test }\end{array}$} & $95 \times 285$ & - & - & - & - & - & 2 & 58.5 & 2 \\
\hline & $95 \times 285$ & AFRP & 0.169 & $19 \%$ & 3732 & 1 & 2 & 58.5 & 2 \\
\hline & $95 \times 285$ & PET FRP & 0.841 & $31 \%$ & 751 & 1 & 2 & 58.5 & 2 \\
\hline & $95 \times 285$ & PET FRP & 0.841 & $31 \%$ & 751 & 1 & 3 & 58.5 & 2 \\
\hline & $95 \times 285$ & PET FRP & 0.841 & $31 \%$ & 751 & 1 & 4 & 58.5 & 2 \\
\hline & $95 \times 285$ & PET FRP & 0.841 & $31 \%$ & 751 & 1 & 5 & 58.5 & 2 \\
\hline
\end{tabular}

A large-capacity drop-weight setup was used for the impact test [23], consisting of a hammerhead with a weight of $188 \mathrm{~kg}, 14$ balancing weights each with a weight of $68 \mathrm{~kg}$, a steel frame, a track, a control system, and a lifting device (Figure 4). The maximum drop height was $16 \mathrm{~m}$. Different impact energies can be obtained by adjusting the mass of the drop weight and the drop height. In this test, the drop weight was held the same at $256 \mathrm{~kg}$ (the hammerhead + one balancing weight), and different impact energies were achieved by varying the impact height (i.e., 2, 3, 4, and $5 \mathrm{~m}$ ).

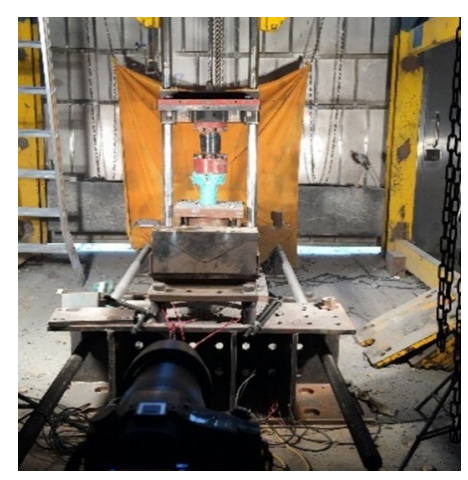

Figure 4. Drop-weight test setup.

\section{Results and Discussion}

Figure 5 shows the typical stress-strain curves of the PET fiber bundle specimens at different strain rates. The curves exhibit a bilinear stress-strain relationship and a rapid drop from the peak stress to zero, which indicates a brittle fracture of the PET fiber bundle. The tensile strength, the elastic modulus, the failure strain, and the toughness are sensitive to the strain rate. When the strain rate increased from $1 / 600$ to $160 \mathrm{~s}^{-1}$, there was an increase in the tensile strength, which can be attributed to the fact that there was not enough time for the defects of filaments in the fiber bundle to develop at a high strain rate [45]. The initial elastic modulus and the second elastic modulus (i.e., slopes of the two portions of the stress-strain curve) increased with an increase in the strain rate from 1/600 to $160 \mathrm{~s}^{-1}$. Conversely, there was a decrease in the failure strain and the toughness with the increasing strain rate from $1 / 600$ to $160 \mathrm{~s}^{-1}$. Figure 6 shows the failure modes of the PET fiber bundles at different strain rates. At a low strain rate (e.g., 1/600 s ${ }^{-1}$ ), the fracture surface of the fiber bundle had a chaotic appearance with different fracture positions of filaments. At a high strain rate (e.g., $160 \mathrm{~s}^{-1}$ ), the fiber bundle ruptured with a relatively trim fractography. 


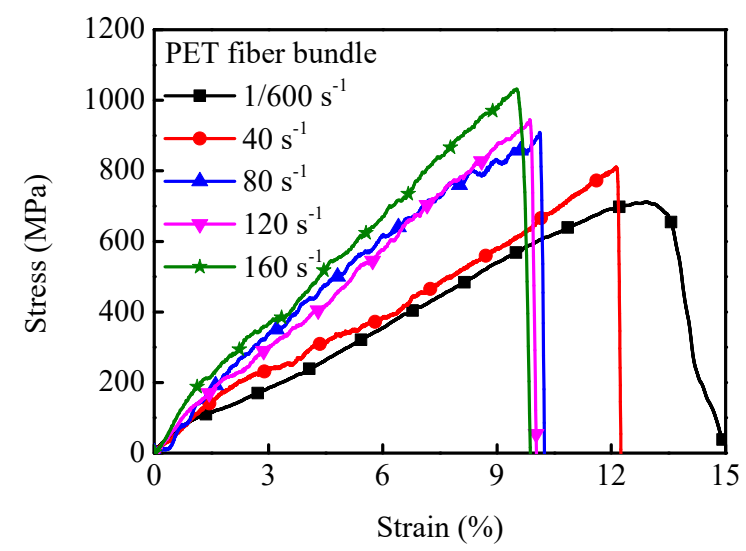

Figure 5. Tensile stress-strain curves of the PET fiber bundle at different strain rates.

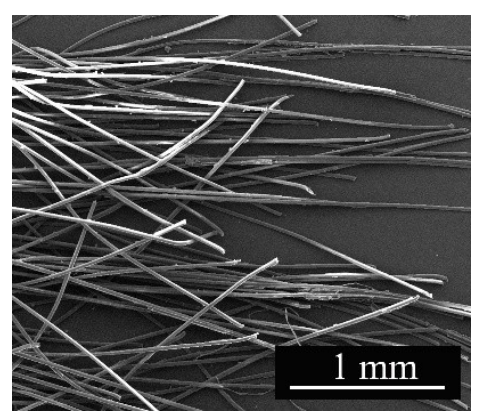

(a)

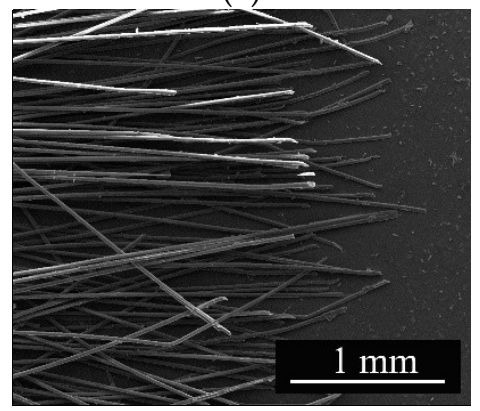

(c)

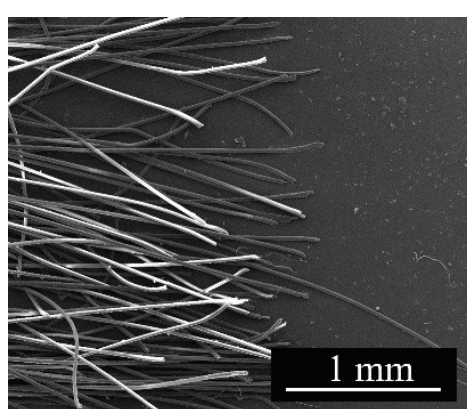

(b)

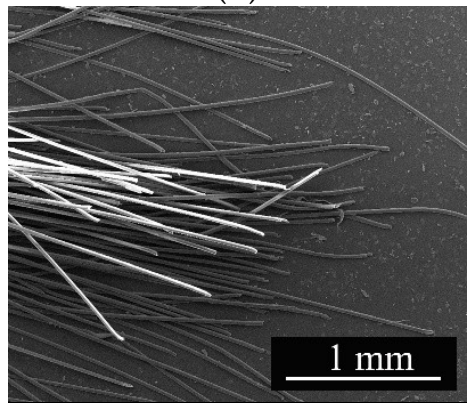

(d)

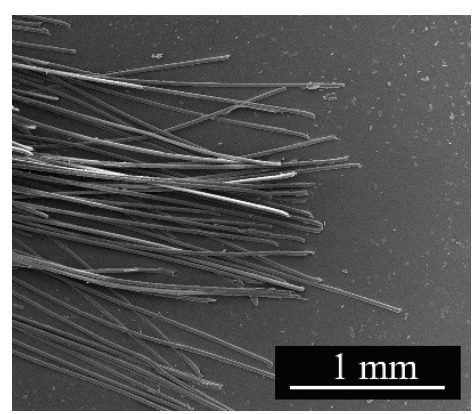

(e)

Figure 6. SEM images of failure modes at the strain rates of $1 / 600 \mathrm{~s}^{-1}(\mathbf{a}) ; 40 \mathrm{~s}^{-1}(\mathbf{b}) ; 80 \mathrm{~s}^{-1}$ (c); $120 \mathrm{~s}^{-1}$ (d); $160 \mathrm{~s}^{-1}(\mathbf{e})$.

Figure 7a shows the failure mode of one layer of the CFRP-confined concrete at a strain rate of $218 \mathrm{~s}^{-1}$ from SHPB tests. At a strain rate of about $220 \mathrm{~s}^{-1}$, one layer of the CFRP-confined concrete was smashed together with the external FRP rupture, whereas, due to its very large rupture strain, two layers of the PET FRP-confined concrete could not be destroyed (Figure 7b). Therefore, to investigate the failure mechanism of the concrete confined with the PET FRP, the specimen was repeatedly impacted under the same impact velocity until failure (Figure 7b). As shown in Figure 7b, only a small piece of 
the concrete was peeled off the surface of concrete confined with the PET FRP after the second impact with a strain rate of $272 \mathrm{~s}^{-1}$. Under the third impact at a strain rate of $280 \mathrm{~s}^{-1}$, partial concrete was crushed with no rupture of the external PET FRP.

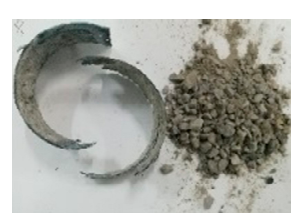

$218 \mathrm{~s}^{-1}$

(a)

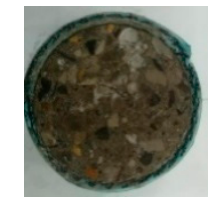

$1^{\text {st }}$ impact $\left(222 \mathrm{~s}^{-1}\right)$

Figure 7. Failure modes of the concrete confined with the CFRP (a) and the PET FRP (b).

Figure 8 shows the dynamic stress-strain curves of specimens confined with the CFRP and the PET FRP at a strain rate of around $220 \mathrm{~s}^{-1}$. The PET and CFRPs were designed for a comparison based on ultimate jacket strengths (i.e., the product of tensile strength and thickness of FRP jacket). One layer of the CFRP provides an ultimate jacket strength of $729.8 \mathrm{~N} / \mathrm{mm}$ that falls between the values provided by one layer and two layers of the PET FRPs $(631.6 \mathrm{~N} / \mathrm{mm}$ and $1263.2 \mathrm{~N} / \mathrm{mm}$, respectively). The dynamic compressive strength of the specimen confined with one layer of the CFRP was $89.4 \mathrm{MPa}$, whereas the corresponding value for one layer of the PET FRP-confined concrete was $82.9 \mathrm{MPa}$ with a larger compressive strain of $4.58 \%$. In addition, the dynamic compressive strength and the corresponding strain of two layers of the PET FRP confined-concrete were remarkably higher than those of the CFRP-confined counterpart, indicating the superior impact performance of the PET FRP-confined concrete due to the large rupture strain characteristic.

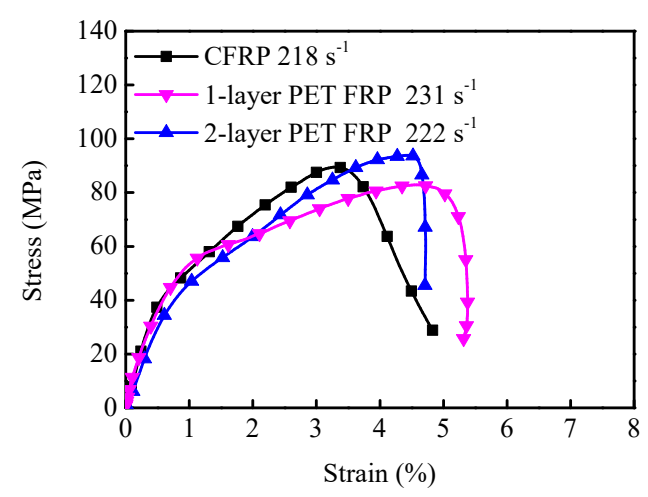

Figure 8. Comparison of the dynamic compressive stress-strain curves of the specimen at a strain rate of around $220 \mathrm{~s}^{-1}$.

Figure 9 shows the dynamic compressive stress-strain curves of the specimen confined with two layers of the PET FRP under multiple impacts. The compressive strength of two layers of the PET FRP-confined concrete decreased after the second impact due to the progressive concrete damage, which reveals superior impact-resistant behavior as far as deformability is concerned due to the large rupture strain characteristic. 


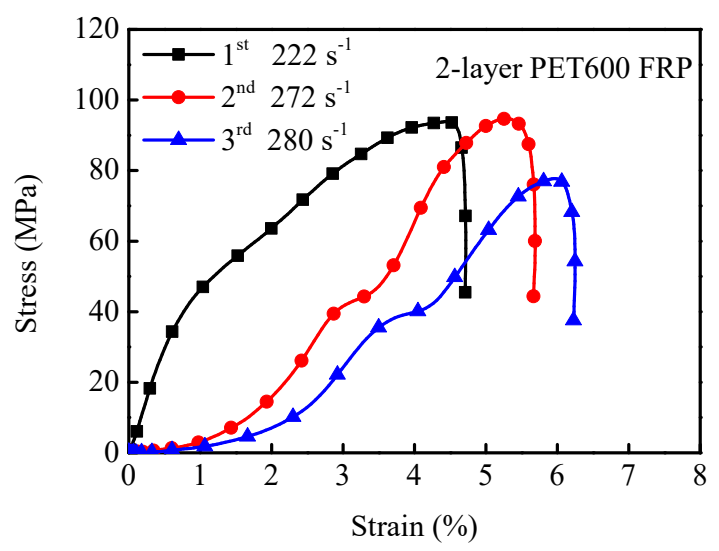

Figure 9. Dynamic compressive stress-strain curves of the specimen confined with two layers of the PET FRP under multiple impacts.

Figure 10a shows the time histories of specimens with three different confining conditions (i.e., no FRP, one layer of AFRP, and PET FRP) under the same drop height of $2 \mathrm{~m}$ from the drop-weight tests. It can be seen that, compared to the unconfined specimen, the application of AFRP led to an increase in the peak impact force. It can also be seen in Figure 10a that the application of PET FRP not only improved the peak impact force, but also prolonged the impact process, leading to a superior impact resistance. Figure 10b shows the time histories of the identical PET FRP-confined specimens tested at different drop heights. As can be seen in Figure 10b, the peak impact force of the specimen slightly increased, and the impact duration gradually decreased with the increasing drop height from 2 to $5 \mathrm{~m}$. It is worth noting that the duration of the specimen impacted under a $4 \mathrm{~m}$ drop height was longer than that of the counterpart under a $3 \mathrm{~m}$ drop height, which can be considered a test scatter in this study.

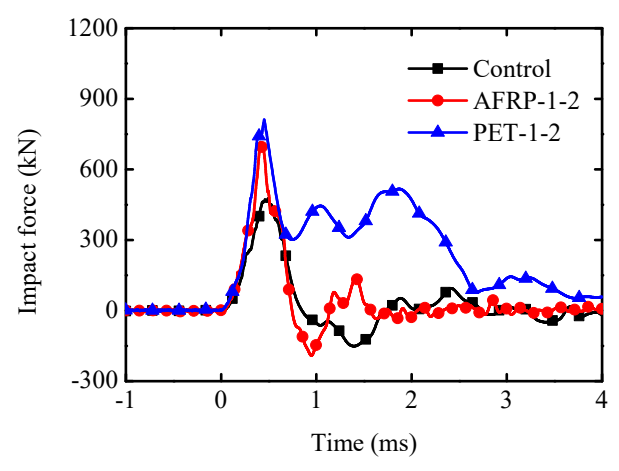

(a)

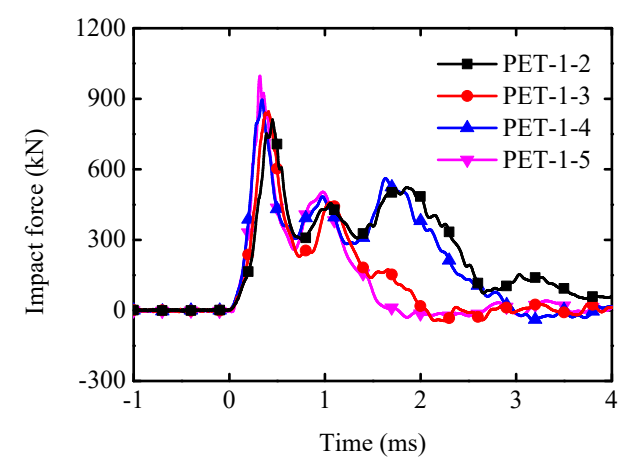

(b)

Figure 10. Impact force time histories of the FRP-confined concrete with different confining conditions (a) and different drop heights (b).

\section{Conclusions}

Based on the dynamic tensile test of PET fiber bundles, the SHPB test, and the drop weight test of the PET FRP-confined concrete, the following conclusions can be drawn:

1. PET fiber bundle is a strain rate-sensitive material. The tensile strength and the elastic modulus increased, whereas the failure strain and the toughness decreased with the increasing strain rate from $1 / 600$ to $160 \mathrm{~s}^{-1}$.

2. Two layers of the PET FRP-confined concrete survived after a single impact compared to its counterpart confined with one layer of the CFRP that can be crushed into pieces under a similar strain rate of about $220 \mathrm{~s}^{-1}$.

3. The dynamic compressive strength of the PET FRP-confined concrete experienced a decrease under multiple impacts with the same impact energy due to the progressive damage of concrete. 
4. The application of the PET FRP for the concrete column not only increased the peak impact-resistance force of columns, but also led to a prolonged impact duration.

Author Contributions: J.-F.J., T.O., J.-G.D. and J.-B.J. conceived and designed the experiments; Y.-L.B. and Z.-W.Y. performed the experiment, analyzed the data and wrote the paper; J.-F.J. and T.O. monitored the experimental process; all authors contributed to the authoring of the paper.

Funding: This research was funded by National Key R\&D Programs of China (2017YFE0103000) and the National Natural Science Foundation of China (grant numbers: 51778019, 51678014, and 51578030).

Conflicts of Interest: The authors declare no conflicts of interest.

\section{References}

1. Teng, J.G.; Chen, J.F.; Smith, S.T.; Lam, L. FRP-Strengthened RC Structures; John Wiley \& Sons: New York, NY, USA, 2002.

2. Ozbakkaloglu, T.; Jian, C.L.; Vincent, T. FRP-confined concrete in circular sections: Review and assessment of stress-strain models. Eng. Struct. 2013, 49, 1068-1088. [CrossRef]

3. Hollaway, L.C.; Teng, J.G. Strengthening and Rehabilitation of Civil Infrastructures Using Fibre-Reinforced Polymer (FRP) Composites; Woodhead Publishing Ltd.: Cambridge, UK, 2008.

4. Ozbakkaloglu, T.; Saatcioglu, M. Displacement-based model to predict lateral drift capacities of concrete-filled FRP tube columns. Eng. Struct. 2017, 147, 345-355. [CrossRef]

5. Wang, Y.L.; Cai, G.C.; Li, Y.Y.; Waldmann, D.; Larbi, A.S.; Tsavdaridis, K.D. Behavior of Circular Fiber-Reinforced Polymer-Steel-Confined Concrete Columns Subjected to Reversed Cyclic Loads: Experimental Studies and Finite-Element Analysis. J. Struct. Eng. 2019, 145, 04019085. [CrossRef]

6. Wang, G.L.; Dai, J.G.; Bai, Y.L. Seismic retrofit of exterior RC beam-column joints with bonded CFRP reinforcement: An experimental study. Compos. Struct. 2019, 224, 111018. [CrossRef]

7. Guo, Y.C.; Gao, W.Y.; Zeng, J.J.; Duan, Z.J.; Ni, X.Y.; Peng, K.D. Compressive behavior of FRP ring-confined concrete in circular columns: Effects of specimen size and a new design-oriented stress-strain model. Constr. Build. Mater. 2019, 201, 350-368. [CrossRef]

8. Ozbakkaloglu, T.; Saatcioglu, M. Seismic behavior of high-strength concrete columns confined by fiber-reinforced polymer tubes. J. Compos. Constr. 2006, 10, 538-549. [CrossRef]

9. Idris, Y.; Ozbakkaloglu, T. Seismic Behavior of High-Strength Concrete-Filled FRP Tube Columns. J. Compos. Constr. ASCE 2013, 17, 04013013. [CrossRef]

10. Ozbakkaloglu, T.; Idris, Y. Seismic Behavior of FRP-High-Strength Concrete-Steel Double-Skin Tubular Columns. J. Struct. Eng. ASCE 2014, 140, 04014019. [CrossRef]

11. Idris, Y.; Ozbakkaloglu, T. Behavior of square fiber reinforced polymer-high-strength concrete-steel double-skin tubular columns under combined axial compression and reversed-cyclic lateral loading. Eng. Struct. 2016, 118, 307-319. [CrossRef]

12. Wang, Y.L.; Chen, G.P.; Wan, B.L.; Cai, G.C.; Zhang, Y.W. Behavior of circular ice-filled self-luminous FRP tubular stub columns under axial compression. Constr. Build. Mater. 2020, 232, 17287. [CrossRef]

13. Mohammadi, M.; Dai, J.G.; Wu, Y.F.; Bai, Y.L. Development of extended Drucker-Prager model for non-uniform FRP-confined concrete based on triaxial tests. Constr. Build. Mater. 2019, 224, 1-18. [CrossRef]

14. Jiang, J.F.; Li, P.D.; Nisticò, N. Local and global prediction on stress-strain behavior of FRP-confined square concrete sections. Compos. Struct. 2019, 226, 111205. [CrossRef]

15. Ou, Y.F.; Zhu, D.J.; Zhang, H.A.; Yao, Y.M.; Mobasher, B.; Huang, L. Mechanical properties and failure characteristics of CFRP under intermediate strain rates and varying temperatures. Compos. Part B Eng. 2016, 95, 123-136. [CrossRef]

16. Al-Salloum, Y.; Almusallam, T.; Ibrahim, S.M.; Abbas, H.; Alsayed, S. Rate dependent behavior and modeling of concrete based on SHPB experiments. Cem. Concr. Compos. 2015, 55, 34-44. [CrossRef]

17. Grote, D.L.; Park, S.W.; Zhou, M. Dynamic behavior of concrete at high strain rates and pressures: I. experimental characterization. Int. J. Impact Eng. 2001, 25, 869-886. [CrossRef]

18. Chen, X.D.; Wu, S.X.; Zhou, J.K. Compressive Strength of Concrete Cores under High Strain Rates. J. Perform. Constr. Facil. 2015, 29, 06014005. [CrossRef] 
19. Zhao, D.B.; Yi, W.J.; Kunnath, S.K. Numerical simulation and shear resistance of reinforced concrete beams under impact. Eng. Struct. 2018, 166, 387-401. [CrossRef]

20. Xie,Z.H.; Duan, Z.J.; Guo, Y.C.; Li, X.; Zeng, J.J. Behavior of Fiber-Reinforced Polymer-Confined High-Strength Concrete under Split-Hopkinson Pressure Bar (SHPB) Impact Compression. Appl. Sci. 2019, 9, 2830. [CrossRef]

21. Ding, Y.; Liu, J.P.; Bai, Y.L. Linkage of multi-scale performances of nano-CaCO3 modified ultra-high performance engineered cementitious composites (UHP-ECC). Constr. Build. Mater. 2020, 234, 117418. [CrossRef]

22. Shan, J.H.; Chen, R.; Zhang, W.X.; Xiao, Y.; Yi, W.J.; Lu, F.Y. Behavior of Concrete Filled Tubes and Confined Concrete Filled Tubes under High Speed Impact. Adv. Struct. Eng. 2007, 10, 209-218. [CrossRef]

23. Xiao, Y.; Shen, Y.L. Impact Behaviors of CFT and CFRP Confined CFT Stub Columns. J. Compos. Constr. 2012, $16,662-670$.

24. Pham, T.M.; Hao, H. Review of concrete structures strengthened with FRP against impact loading. Structures 2016, 7, 59-70. [CrossRef]

25. Pham, T.M.; Hao, H. Axial Impact Resistance of FRP-Confined Concrete. J. Compos. Constr. 2017, 21, 04016088. [CrossRef]

26. Huang, L.; Sun, X.X.; Yan, L.B.; Kasal, B. Impact behavior of concrete columns confined by both GFRP tube and steel spiral reinforcement. Constr. Build. Mater. 2017, 131, 438-448. [CrossRef]

27. Yang, H.; Song, H.W.; Zhang, S. Experimental investigation of the behavior of aramid fiber reinforced polymer confined concrete subjected to high strain-rate compression. Constr. Build. Mater. 2015, 95, 143-151. [CrossRef]

28. Ou, Y.F.; Zhu, D.J.; Zhang, H.A.; Huang, L.; Yao, Y.M.; Li, G.S.; Mobasher, B. Mechanical Characterization of the Tensile Properties of Glass Fiber and Its Reinforced Polymer (GFRP) Composite under Varying Strain Rates and Temperatures. Polymers 2016, 8, 196. [CrossRef]

29. Zhu, D.; Mobasher, B.; Erni, J.; Bansal, S.; Rajan, S.D. Strain rate and gage length effects on tensile behavior of Kevlar 49 single yarn. Compos. Part A Appl. Sci. Manuf. 2012, 43, 2021-2029. [CrossRef]

30. Dai, J.G.; Bai, Y.L.; Teng, J.G. Behavior and Modeling of Concrete Confined with FRP Composites of Large Deformability. J. Compos. Constr. 2011, 15, 963-973. [CrossRef]

31. Bai, Y.L.; Dai, J.G.; Mohammadi, M.; Lin, G.; Mei, S.J. Stiffness-based design-oriented compressive stress-strain model for large-rupture-strain (LRS) FRP-confined concrete. Compos. Struct. 2019, 223, 110953. [CrossRef]

32. Bai, Y.L.; Dai, J.G.; Teng, J.G. Cyclic Compressive Behavior of Concrete Confined with Large Rupture Strain FRP Composites. J. Compos. Constr. 2014, 18, 04013025. [CrossRef]

33. Dai, J.G.; Lam, L.; Ueda, T. Seismic retrofit of square RC columns with polyethylene terephthalate (PET) fibre reinforced polymer composites. Constr. Build. Mater. 2012, 27, 206-217. [CrossRef]

34. Saleem, S.; Hussain, Q.; Pimanmas, A. Compressive Behavior of PET FRP-Confined Circular, Square, and Rectangular Concrete Columns. J. Compos. Constr. 2017, 21, 04016097. [CrossRef]

35. Bai, Y.L.; Dai, J.G.; Teng, J.G. Monotonic Stress-Strain Behavior of Steel Rebars Embedded in FRP-Confined Concrete Including Buckling. J. Compos. Constr. 2017, 21, 04017043. [CrossRef]

36. Bai, Y.L.; Dai, J.G.; Teng, J.G. Buckling of steel reinforcing bars in FRP-confined RC columns: An experimental study. Constr. Build. Mater. 2017, 140, 403-415. [CrossRef]

37. Bai, Y.L.; Dai, J.G.; Ozbakkaloglu, T. Cyclic stress-strain model incorporating buckling effect for steel reinforcing bars embedded in FRP-confined concrete. Compos. Struct. 2017, 182, 54-66. [CrossRef]

38. Anggawidjaja, D.; Ueda, T.; Dai, J.; Nakai, H. Deformation capacity of RC piers wrapped by new fiber-reinforced polymer with large fracture strain. Cem. Concr. Compos. 2006, 28, 914-927. [CrossRef]

39. Ispir, M. Monotonic and Cyclic Compression Tests on Concrete Confined with PET-FRP. J. Compos. Constr. 2014, 19, 04014034. [CrossRef]

40. Huang, L.; Zhang, S.S.; Yu, T.; Wang, Z.Y. Compressive behaviour of large rupture strain FRP-confined concrete-encased steel columns. Constr. Build. Mater. 2018, 183, 513-522. [CrossRef]

41. Bai, Y.L.; Yan, Z.W.; Ozbakkaloglu, T.; Han, Q.; Dai, J.G.; Zhu, D.J. Quasi-static and dynamic tensile properties of large-rupture-strain (LRS) polyethylene terephthalate fiber bundle. Constr. Build. Mater. 2020, 232, 117241. [CrossRef] 
42. Zeng, J.J.; Gao, W.Y.; Duan, Z.J.; Bai, Y.L.; Guo, Y.C.; Ouyang, L.J. Axial compressive behavior of polyethylene terephthalate/carbon FRP-confined seawater sea-sand concrete in circular columns. Constr. Build. Mater. 2020, 234, 117383. [CrossRef]

43. Kurihashi, Y.; Mikami, H.; Komuro, M.; Kishi, N. Effect of sheet volume on impact resistant capacity of RC beam strengthened with AFRP sheet. In Proceedings of the 8th Inernational Conference on Fiber-Reinforced Polymer (FRP) Composites in Civil Engineering (CICE 2016), Hong Kong, China, 14-16 December 2016.

44. Ou, Y.F.; Zhu, D.J. Tensile behavior of glass fiber reinforced composite at different strain rates and temperatures. Constr. Build. Mater. 2015, 96, 648-656. [CrossRef]

45. Ou, Y.F.; Zhu, D.J.; Huang, M.Y.; Li, H. The effects of gage length and strain rate on tensile behavior of Kevlar (R) 29 single filament and yarn. J. Compos. Mater. 2017, 51, 109-123. [CrossRef]

C 2019 by the authors. Licensee MDPI, Basel, Switzerland. This article is an open access article distributed under the terms and conditions of the Creative Commons Attribution (CC BY) license (http://creativecommons.org/licenses/by/4.0/). 